\title{
PEMETAAN GAYA DAN TIPE KEPEMIMPINAN KEPALA SEKOLAH
}

\author{
Sunarni \\ Desi Eri Kusumaningrum \\ Djum Djum Noor Benty \\ Fakultas Ilmu Pendidikan, Universitas Negeri Malang \\ Jalan Semarang No. 5 Malang \\ email: jengnarni@yahoo.co.id
}

\begin{abstract}
The purpose of this research is to know style, type, leadership style, and leadership type that most dominant of headmasters of state primary schools, state junior and senior high school in Malang City. Quantitative approach with descriptive exploratory analysis design. Population (136) headmasters of state primary schools, state junior and senior high school in Malang City, sample of random sampling 41 people. Data collection techniques use questionnaire, factor analysis and descriptive. Outcome: (1) 5 types of leadership style, that is democratic, delegative, militaristic/autocratic, exploitative, and consultative, (2) leadership type that is administrative/ executive, democratic, populist/nationalistic, charismatic and authoritarian/autocratic, (3) the most dominant democratic style the headmaster answered agree, the delegative style and consultative answer agreed, militaristic/autocratic style and exploitative less agree. (4) administrative/executive type, democratic, charismatic, and authoritarian, the most dominant principal responds agree, and populist/nationalistic type responds less agree.
\end{abstract}

Keyword: leadership style, leadership type, headmaster

\begin{abstract}
Abstrak: Tujuan penelitian mengetahui gaya, tipe, gaya kepemimpinan paling dominan, dan tipe kepemimpinan paling dominan kepala sekolah SD, SMP, dan SMA Negeri Kota Malang. Pendekatan kuantitatif dengan rancangan analisis deskriptif eksploratori. Populasi (136) orang kepala SD, SMP, dan SMA Negeri se-Kota Malang, sampel random sampling 41 orang. Teknik pengumpulan data angket, analisis faktor dan deskriptif. Hasil: (1) gaya kepemimpinan ada 5 macam yaitu demokratik, delegatif, militeristik/otokratis, eksploitatif, dan konsultatif, (2) tipe kepemimpinan yaitu administratif/eksekutif, demokratis, populistik/nasionalistik, karismatik, dan otoriter/otokratis, (3) gaya demokratik paling dominan kepala sekolah menjawab setuju, gaya delegatif dan konsultatif menjawab setuju, gaya militeristik/otokratis) dan eksploitatif kurang setuju, (4) tipe administrative/eksekutif), demokratik, karismatik, dan otoriter yang paling dominan kepala sekolah menjawab setuju, dan tipe populistik/nasionalistik) menjawab kurang setuju.
\end{abstract}

Kata kunci: gaya kepemimpinan, tipe kepemimpinan, kepala sekolah

Berdasarkan tujuan pendidikan nasional, peran pemimpin dalam bidang pendidikan sangat berpengaruh untuk mewujudkan tujuanan. Pemimpin dalam bidang pendidikan, terdiri dari kepala satuan pendidikan dari tingkat pendidikan pra-sekolah, pendidikan dasar, pendidikan menengah, maupun pendidikan tinggi. Untuk menjadi seorang pemimpin ada 3 macam yang mendasarinya yaitu faktor keturunan, faktor sosial, dan faktor ekologis. Ciri karakteristik seorang pemimpin menurut Stephen 
J. Knezevich (dalam Soetopo, 2010) adalah: (1) kepemimpinan simbolik yang mempunyai ciri: ramah, jujur, besemangat, kreatif, tabah, bijaksana, cerdas, humoris, lemah lembut, dan ada yang mempertimbangkan bentuk tubuh, (2) kepemimpinan formal (karena posisi, gelar, jabatan, puncak hierarkhi, kuasa), dan (3) kepemimpinan fungsional (karena peranan, fungsi, dan kemanfaatan bagi kelompok).

Kepala sekolah sebagai pemimpin di bidang pendidikan harus memahami konsep dasar kepemimpinan pendidikan yang terdiri dari: prinsipprinsip, fungsi, jenis-jenis kepemimpinan, gaya kepemimpinan, tipe-tipe kepemimpinan, syaratsyarat kepribadian, keterampilan-keterampilan yang diperlukan (komunikasi, pengambilan keputusan, pengelolaan konflik), faktor-faktor yang mempengaruhi, dan orientasi kepemimpinan pendidikan. Menurut standar Kepala Sekolah/Madrasah Peraturan Menteri Pendidikan Nasional Republik Indonesia No. 13 tahun 2007 menyatakan bahwa kepala sekolah/madrasah harus mempunyai kualifikasi umum dan kualifikasi khusus. Mempunyai kompetensi: kepribadian, manajerial, kewirausahaan, supervisi, dan sosial.

Kenyataan di lapangan, karena sejak diberlakukan otonomi daerah di Indonesia yang didasarkan pada Undang-Undang Nomor 32 Tahun 2004 tentang Pemerintah Daerah. Kehadiran ini, memberikan peluang lebih besar bagi daerah untuk mengelola pendidikan secara mandiri sesuai dengan kesiapan daerah bersangkutan. Dengan adanya otonomi daerah, pengaruh politik sangat kental dirasakan. Bagi orang-orang yang mendukung calon Wali Kota/Bupati dalam Pemilu Daerah (Pilkada) dan menang, maka orang-orang itu yang akan mendapat peran penting nantinya (walaupun tidak mempunyai kapasitas sama sekali), dan bagi yang tidak mendukung, maka orang-orang itu akan disingkirkan (walaupun orang ini sangat potensial).

Hal ini juga terjadi di dalam pendidikan. Orang-orang yang diangkat menjadi pemimpin dalam bidang pendidikan, kadang tidak mempunyai kapasitas untuk menjadi seorang pemimpin. Apabila ini terjadi secara terus-menerus, maka lama kelamaan tujuan pendidikan yang dicita-citakan tidak akan segera tercapai. Oleh karena itu, sebagai seorang pemimpin pendidikan perlu memahami konsep dasar kepemimpinan pendidikan, yaitu gaya dan tipe kepemimpinan pendidikan. Karena dengan mengetahui gaya kepemimpinannya, seseorang akan mengetahui bagaimana menjalankan fungsi kepemimpinan, yang mempunyai cara masingmasing yang tercermin dari perilakunya, sedangkan apabila seseorang mengetahui tipe-tipe kepemimpinan, maka seorang pemimpin akan mengetahui apa saja yang harus diperbuat untuk memimpin bawahan. Senada dengan Soetopo (2010:9) menyatakan bahwa apabila seseorang mengetahui tipe kepemimpinan yang mereka miliki, maka orang tersebut akan mengetahui cara kerja dan cara bergaul dan dapat dipertanggungjawabkan dan dapat menggerakkan orang lain.

Selain itu kepala sekolah juga perlu memahami betapa pentingnya system informasi dalam pengambilan keputusan. Kepala sekolah sebagai seorang manajer, harus memahami posisi dari hierarki/tingkatan manajemen dimana seorang manejer itu berada. Ada 3 tingkatan tugas manajerial antara lain lower management, middle management, dan top management, hal ini sangat penting bagi seorang pimpinan. Semakin rendah kedudukan seseorang sebagai pimpinan, maka membutuhkan sumber informasi dari internal organisai (lingkungan intern) sekolah dalam bentuk detail/terperinci dan terstruktur. Jika kedudukan seseorang semakin tinggi, maka membutuhkan informasi dari luar organisasi (lingkungan luar) dalam bentuk summary/ringkasan dan tidak terstruktur (Gandz \& Murray, 1980).

Hasil penelitian tentang gaya kepemimpinan bahwa gaya kepemimpinan transformasional secara langsung mempunyai hubungan yang sangat kuat terhadap motivasi kerja karyawan dan gaya kepemimpinan transformasional secara parsial dan simultan berpengaruh terhadap motivasi kerja karyawan (Mondiani, 2012). Selain itu Pratiguna, dkk (2013) yaitu ada pengaruh yang signifikan antara variabel gaya kepemimpinan terhadap variable produktivitas kerja karyawan di Dinas Kesehatan Kabupaten Klaten. Ada pengaruh antara gaya kepemimpinan dengan dimediasi motivasi kerja terhadap produktivitas kerja karyawan tetapi kecil yaitu sebesar $5,5 \%$, sedangkan dengan dimediasi kemampuan kerja terhadap produktivitas kerja karyawan sebesar 44,3\%. Dan hasil penelitian Reza (2010) menyatakan bahwa gaya kepemimpinan berpengaruh terhadap kinerja karyawan, motivasi berpengaruh terhadap kinerja karyawan, dan disiplin kerja berpengaruh terhadap kinerja karyawan. 
Hasil penelitian Mufidah (2009) menyatakan bahwa: (a) mayoritas kepala sekolah SMP se Kota Malang menerapkan gaya kepeminimnan instruktif tingkat tinggi, (b) untuk penerapan gaya kepemimpinan konsultatif pada tingkat sedang, (c) penerapan gaya partisipatif pada tingkat sedang, (d) pada penerapan gaya delegatif tingkat sedang, dan (e) terdapat hubungan tidak langsung secara simultan yang signifikan antara variabel gaya kepemimpinan (X) terhadap kinerja tenaga administrasi sekolah (Y) melalui iklim sekolah (Z) di SMPN Kota Malang.

Dari beberapa hasil penelitian belum menemukan instrumen yang berbasis Teknologi Informasi (TI) untuk mendeteksi tentang gaya dan tipe apa yang dimiliki oleh pemimpin dalam bidang pendidikan. Dari latar belakang penelitian ini, peneliti mengambil judul "Pemetaan Gaya dan Tipe Kepemimpinan Kepala Sekolah.” Berdasarlan latar masalah di atas, maka yang menjadi tujuan dalam penelitian ini adalah untuk mengetahui: (1) gaya kepemimpinan, (2) tipe kepemimpinan, (3) gaya kepemimpinan paling dominan, dan (4) tipe kepemimpinan paling dominan kepala sekolah SD, SMP, dan SMA Negeri di Kota Malang.

\section{METODE}

Penelitian ini menggunakan pendekatan kuantitatif deskriptif. Untuk studi pendahuluan pada tahap ini, penelitian menggunakan pendekatan kuantitatif dengan rancangan analisis deskriptif eksploratori. Analisis deskriptif digunakan untuk menganalisis data dengan cara mendeskripsikan atau menggambarkan data yang telah terkumpul. Menggunakan analisis deskripsi digunakan untuk menemukan gaya kepemimpinan dan tipe kepemimpinan apa saja yang paling dominan dimiliki kepala sekolah Sekolah Dasar (SD), Sekolah Menengah Pertama (SMP), dan Sekolah Menengah Atas (SMA) Negeri di Kota Malang. Sedangkan eksploratori digunakan untuk mencari gaya dan tipe kepemimpinan yang dimiliki kepala sekolah SD, SMP, dan SMA Negeri di Kota Malang.

Populasi penelitian adalah semua kepala sekolah di SD, SMP, dan SMA Negeri se-Kota Malang yang berjumlah 136 orang. Pengambilan sampel dengan proportionate stratitifed random sampling diambil berdasarkan tingkat satuan pendidikan dan diambil 30\% dari populasi. Sampel didapat sebanyak 41 kepala sekolah, terdiri dari 30 kepala SDN, 7 orang kepala SMPN, dan 4 orang kepala SMAN. Data diambil di wilayah pusat kota, tengah, dan pinggiran Kota Malang. Pengumpulan data dalam penelitian ini dengan angket/kuesionare. Data dianalisis dengan analisis faktor dan deskriptif dengan bantuan SPSS for relase 17. Analisis faktor digunakan untuk menyederhanakan teori gaya dan tipe kepemimpinan yang berasal dari berbagai pendapat ahli, yang masing-masing ahli mempunyai cara pandang dan pendapat yang berbeda, sehingga tidak terjadi pelipatgandaan teori. Sedangkan analisis deskriptif digunakan untuk menjawab rumusan masalah yaitu mengetahui gaya dan tipe kepemimpinan pendidikan yang paling dominan di jenjang SD, SMP, dan SMA Negeri di Kota Malang.

\section{HASIL}

\section{Gaya Kepemimpinan Kepala Sekolah SD, SMP, dan SMA Negeri di Kota Malang}

Berdasarkan analisis faktor didapat faktor loding sebanyak 5 faktor, faktor-faktor tersebut dapat dilihat pada tabel 1.

\section{Tipe Kepemimpinan Kepala Sekolah SD, SMP, dan SMA Negeri di Kota Malang}

Sedangkan hasil analisis untuk variabel tipe kepemimpinan, faktor lodingnya dapat dlihat pada tabel 2.

\section{Gaya Kepemimpinan Paling Dominan Kepala Sekolah SD, SMP, dan SMA Negeri di Kota Malang}

Analisis gaya kepemimpinan secara kesuruhan butir atau sebanyak 73 butir pertanyaan, hasilnya adalah pada alternatif jawaban tidak setuju sebanyak $0(0 \%)$, kurang setuju sebanyak $3(7,3 \%)$, jawaban setuju sebanyak 25 orang responden $(61,0 \%)$, dan jawaban sangat setuju sebanyak $13(31,7 \%)$. Sehingga alternatif jawaban setuju merupakan alternatif jawaban terbanyak. Dan hasil dari analisis deskriptif mean statistik mendapatkan 223,37 terletak pada range 3 (setuju).

Analisis gaya kepemimpinan untuk faktor 1 (Demokratik) secara parsial yang terdiri dari 55 pertanyaan, hasilnya adalah pada alternatif jawaban tidak setuju sebanyak $0(0 \%)$, kurang setuju sebanyak 2 (4,9\%), Jawaban setuju sebanyak $22(53,7 \%)$, dan jawaban sangat setuju sebanyak 
17 (41,4\%). Sehingga alternatif jawaban setuju merupakan alternatif jawaban terbanyak. Hasil analisis data deskriptif mean mendapatkan nilai 175,56 yang masuk pada range ke-3 yaitu setuju.

Analisis gaya kepemimpinan untuk faktor 2 (delegatif) secara parsial yang terdiri dari 7 butir pertanyaan, hasilnya adalah pada alternatif jawaban tidak setuju sebanyak $0(0 \%)$, kurang setuju sebanyak $1(2,4 \%)$, Jawaban setuju sebanyak $38(92,7 \%)$, dan jawaban sangat setuju sebanyak $2(4,9 \%)$. Sehingga alternatif jawaban setuju merupakan alternatif jawaban terbanyak. Hasil analisis deskriptif hasil mean sebesar 18,68 yang masuk pada range 3 yaitu setuju.

Analisis gaya kepemimpinan untuk faktor 3 (Militeristik/Otokratis) secara parsial yang terdiri dari 5 pertanyaan, hasilnya adalah pada alternatif jawaban tidak setuju sebanyak $0(0 \%)$, kurang setuju sebanyak 29 (70,7\%), jawaban setuju sebanyak 11 $(26,8 \%)$, dan jawaban sangat setuju sebanyak 1 $(2,4 \%)$. Sehingga alternatif jawaban kurang setuju merupakan alternatif jawaban terbanyak. Hasil analisis deskriptif mendapatkan mean sebesar 11,95 yang berarti masuk ke range 2 (kurang setuju).

Analisis gaya kepemimpinan untuk faktor 4 (eksploitatif) secara parsial yang terdiri dari 2 pertanyaan, hasilnya adalah pada alternatif jawaban tidak setuju sebanyak $0(0 \%)$, kurang setuju sebanyak $23(56,1 \%)$, jawaban setuju sebanyak $17(41,5 \%)$, dan jawaban sangat setuju sebanyak 1 $(2,4 \%)$. Sehingga alternatif jawaban kurang setuju merupakan alternatif jawaban terbanyak. Hasil analisis deskriptif mendapatkan nilai mean sebesar 5,41 yang berarti masuk ke range 2 dan 3 (kurang setuju dan setuju).

Analisis gaya kepemimpinan untuk faktor 5 (konsultatif) secara parsial yang terdiri dari 4 pertanyaan, hasilnya adalah pada alternatif jawaban tidak setuju sebanyak $0(0 \%)$, kurang setuju sebanyak 2 (4,9\%), jawaban Setuju sebanyak $28(68,3 \%)$, dan jawaban sangat setuju sebanyak $11(26,8 \%)$. Sehingga alternatif jawaban setuju merupakan alternatif jawaban terbanyak. Hasil analisis deskriptif mendapatkan mean sebesar 11,76 yang berarti masuk ke

Tabel 1. Faktor Loding Gaya Kepemimpinan

\begin{tabular}{|c|c|c|c|}
\hline Hal & Faktor & Hasil Rotasi & $\begin{array}{c}\text { Penamaan Kat- } \\
\text { egori }\end{array}$ \\
\hline \multirow[t]{5}{*}{$\begin{array}{l}\text { Gaya Kepe- } \\
\text { mimpinan }\end{array}$} & 1 & $\begin{array}{l}\text { X2, X3, X5, X6, X7, X8, X9, X10, X11, X13, X14, } \\
X 15, X 16, X 19, X 20, X 22,23, X 24, X 25, X 26, X 27, \\
X 28, X 30, X 31, X 32, X 33, X 34, X 35, X 36, X 37, X 39, \\
X 40, X 41, X 42, X 44, X 45, X 47, X 48, X 49, X 50, X 51, \\
\text { X52, X54, X55, X56, X57, X59, X60, X62, X63, X64, } \\
\text { X68, X70, X71, X73 }\end{array}$ & Demokratik \\
\hline & 2 & X4, X29, X53, X58, X65, X66, X69 & Delegatif \\
\hline & 3 & $\mathrm{X} 17, \mathrm{X} 18, \mathrm{X} 46, \mathrm{X} 67, \mathrm{X} 72$ & $\begin{array}{l}\text { Militeristik/ } \\
\text { otokratis }\end{array}$ \\
\hline & 4 & $\mathrm{X} 12, \mathrm{X} 62$ & Eksploitatif \\
\hline & 5 & $\mathrm{X} 1, \mathrm{X} 21, \mathrm{X} 38, \mathrm{X} 43$ & Konsultatif \\
\hline
\end{tabular}

Tabel 2. Faktor Loding Tipe Kepemimpinan

\begin{tabular}{|l|c|l|l|}
\hline Hal & Faktor & \multicolumn{1}{|c|}{ Hasil Rotasi } & \multicolumn{1}{|c|}{ Penamaan Kategori } \\
\hline $\begin{array}{l}\text { Tipe Kepe- } \\
\text { mimpinan }\end{array}$ & 1 & $\begin{array}{l}\text { Y18, Y16, Y19, Y20, Y34, Y17, Y39, Y10, Y43, } \\
\text { Y30, Y32, Y4, Y22, Y42, Y41, Y28, Y3, Y25, } \\
\text { Y21, Y27, Y5, Y37, Y23, Y7 }\end{array}$ & $\begin{array}{l}\text { Administratif/ekse- } \\
\text { kutif }\end{array}$ \\
\cline { 2 - 4 } & 2 & Y40, Y35, Y36, Y38, Y9, Y29, Y26, Y8 & Demokratis \\
\cline { 2 - 5 } & 3 & Y24, Y31, Y14, Y33, Y12 & Populistik \\
\cline { 2 - 5 } & 4 & Y2, Y1, Y15 & Karismatik \\
\cline { 2 - 4 } & 5 & Y11, y6, y13 & Otoriter/otokratis \\
\hline
\end{tabular}


Tabel 3. Faktor Gaya Kepemimpinan yang Paling Dominan

\begin{tabular}{|l|l|l|l|}
\hline No & \multicolumn{1}{|c|}{ Faktor } & \multicolumn{1}{c|}{ Gaya } & $\begin{array}{c}\text { Pendapat Kepala Sekolah Terha- } \\
\text { dap Gaya }\end{array}$ \\
\hline 1 & Keseluruhan Butir & Gaya Kepemimpinan & Setuju \\
\hline 2 & F1 & Gaya Demokratik & Setuju \\
\hline 3 & F2 & Gaya Delegatif & Setuju \\
\hline 4 & F3 & Gaya militeristik/otokratis & Kurang Setuju \\
\hline 5 & F4 & Gaya eksploitatif & Kurang Setuju \\
\hline 6 & F5 & Gaya konsultatif & Setuju \\
\hline
\end{tabular}

Tabel 4. Kecenderungan Gaya Kepala Sekolah

\begin{tabular}{|c|l|c|c|c|c|c|c|}
\hline No. & Sekolah & $\begin{array}{c}\text { F1 } \\
\text { Demokratif }\end{array}$ & $\begin{array}{c}\text { F2 } \\
\text { Delegatif }\end{array}$ & $\begin{array}{c}\text { Militeristik \& } \\
\text { Otokratis }\end{array}$ & $\begin{array}{c}\text { F4 } \\
\text { Eksploitatif }\end{array}$ & $\begin{array}{c}\text { F5 } \\
\text { Konsultatif }\end{array}$ & $\begin{array}{c}\text { Jumlah } \\
(\%)\end{array}$ \\
\hline 1 & SD & 9 & 8 & 7 & 46 & 30 & $100 \%$ \\
2 & SMP & 7 & 6 & 6 & 27 & 54 & $100 \%$ \\
\hline 3 & SMA & 22 & 17 & 13 & 32 & 16 & $100 \%$ \\
\hline
\end{tabular}

range 3 (setuju). Dari jabaran di atas dapat dilihat pada tabel 3 .

Kecenderungan gaya yang dimiliki masingmasing tingkatan sekolah dari SD, SMP, dan SMA dapat dilihat pada Tabel 4. Bahwa di tingkat SD kepala sekolah cenderung mempunyai gaya eksploitatif, jika di tingkat SMP gaya kepala sekolah cenderung konsultatif, dan di tingkat SMA gaya kepala sekolah cenderung eksploitatif juga.

\section{Tipe Kepemimpinan Paling Dominan Kepala SD, SMP, dan SMA Negeri di Kota Malang}

Tipe kepemimpinan yang paling dominan yang dimiliki oleh kepala sekolah SDN, SMPN, dan SMAN di Kota Malang, secara keseluruhan hasil yang terdiri dari 43 pertanyaan adalah pada alternatif jawaban tidak setuju sebanyak $0(0 \%)$, kurang setuju sebanyak $7(17,1 \%)$, jawaban setuju sebanyak $31(75,6 \%)$, dan jawaban sangat setuju sebanyak $3(7,3 \%)$. Sehingga alternatif jawaban Setuju merupakan alternatif jawaban terbanyak. Hasil analisis deskriptif menghasilkan mean sebesar 119,27 yang berarti masuk ke range 3 (setuju).

Analisis tipe kepemimpinan untuk faktor 1 (Administratif/Eksekutif) secara parsial yang terdiri dari 24 pertanyaan, hasilnya adalah pada alternatif jawaban tidak setuju sebanyak $1(2,4 \%)$, kurang setuju sebanyak $10(24,4 \%)$, jawaban setuju sebanyak $23(56,1 \%)$, dan jawaban sangat setuju sebanyak $7(17,1 \%)$. Sehingga alternatif jawaban setuju merupakan alternatif jawaban terbanyak. Dari analisis deskriptif mendapatkan mean sebesar 66,54 masuk pada range ke-3 (setuju).

Analisis tipe kepemimpinan untuk faktor 2 (Demokratis) secara parsial yang terdiri dari 8 pertanyaan, hasilnya adalah pada alternatif jawaban tidak setuju sebanyak $0(0 \%)$, kurang setuju sebanyak $0(0 \%)$, jawaban setuju sebanyak $31(75,6 \%)$, dan jawaban sangat setuju sebanyak $10(24,4 \%)$. Sehingga alternatif jawaban setuju merupakan alternatif jawaban terbanyak. Hasil analisis deskriptif mendapatkan mean sebesar 24,49 yang masuk pada range ke-3 yaitu setuju.

Analisis tipe kepemimpinan untuk faktor 3 (Populistik) secara parsial yang terdiri dari 5 pertanyaan, hasilnya adalah pada alternatif jawaban tidak setuju sebanyak $0(0 \%)$, kurang setuju sebanyak $24(58,5 \%)$, jawaban Setuju sebanyak $17(41,5 \%)$, dan jawaban Sangat Setuju sebanyak $0(0 \%)$. Sehingga alternatif jawaban kurang setuju merupakan alternatif jawaban terbanyak. Analisis deskriptif mendapatkan nilai mean sebesar 12,24 yang masuk pada range ke-2 (kurang setuju).

Analisis Tipe kepemimpinan untuk faktor 4 (Karismatik) secara parsial yang terdiri dari 3 pertanyaan, hasilnya adalah pada alternatif jawaban tidak setuju sebanyak $0(0 \%)$, kurang setuju sebanyak 4 $(34,1 \%)$, jawaban Setuju sebanyak $27(65,9 \%)$, dan jawaban sangat setuju sebanyak $0(0 \%)$. Sehingga alternatif jawaban Setuju merupaka alternatif jawa- 
ban terbanyak. Hasil analisis deskriptif hasil mean sebesar 7,98 yang masuk pada range 3 (setuju).

Analisis tipe kepemimpinan untuk faktor 5 (Otoriter/Otokratis) secara parsial yang terdiri dari 3 pertanyaan, hasilnya adalah pada alternatif jawaban tidak setuju sebanyak $0(0 \%)$, kurang setuju sebanyak 14 (34,1\%), jawaban setuju sebanyak $26(63,4 \%)$, dan jawaban sangat setuju sebanyak 1 $(2,4 \%)$. Sehingga alternatif jawaban Setuju merupakan alternatif jawaban terbanyak. Analisis data deskriptif mendapatkan nilai mean sebesar 8,02 masuk pada range 3 (setuju). Tipe kepemimpinan pendidikan yang paling dominan dapat dilihat pada Tabel 5 .

Kecenderungan tipe yang dimiliki masingmasing tingkatan sekolah dari SD, SMP, dan SMA Negeri dapat dilihat pada Tabel 6. Untuk tipe kepemimpinan pendidikan di tingkat SD hingga SMA cenderung demokratik.

\section{PEMBAHASAN}

Gaya Kepemimpinan Kepala Sekolah SD, SMP, dan SMA Negeri di Kota Malang

Hasil penelitian menunjukkan gaya kepemimpinan yang dimiliki Kepala Sekolah SD, SMP, dan SMA Negeri di Kota Malang dikelompokkan menjadi 5 macam gaya, yaitu demokratik, delegatif, militeristik, eksploitatif, dan konsultatif. Kepe- mimpinan merupakan kemampuan mempengaruhi orang lain, bawahan atau kelompok, kemampuan mengarahkan tingkah laku bawahan atau kelompok, memiliki kemampuan atau keahlian khusus dalam bidang yang diinginkan oleh kelompoknya, untuk mencapai tujuan organisasi atau kelompok (Tangkilisan, 2005). Sedangkan kepemimpinan pendidikan merupakan kemampuan untuk menggerakkan dan membimbing orang yang terlibat dalam pelaksanaan pendidikan untuk mencapai tujuan pendidikan (Soetopo, 2010). Kepala Sekolah berfungsi dan bertugas sebagai Edukator, Manajer, Administrator, Supervisor, Pemimpin/Leader, Inovator, Motivator (Pujianto, 2015).

Gaya kepemimpinan demokratik sesuai dengan pendapat Lewin, Lippitt, \& White (1939) yang mempunyai ciri-ciri: (a) menghargai, perhatian dan menganggap bawahan, melibatkan partisipasi bawahan dalam pengambilan keputusan organisasi, (b) pemimpin bertindak berdasarkan kepercayaan, integrity, kejujuran, equality, openness dan mutual respect, (c) pimpinan memotivasi bawahan untuk mencapai kemampuan tertinggi, adanya kerjasama dengan tim dan tingkat partisipasi bawahan tinggi, (d) pimpinan memfeedback bawahan, dan pimpinan memilih reward dibanding punishment. Menurut pendapat Lewin, Lippitt, \& White (1939) menyatakan bahwa gaya kepemimpinan demokratik: (a) pemimpin mempunyai wewenang pemimpin

Tabel 5. Faktor Tipe Kepemimpinan yang Paling Dominan

\begin{tabular}{|l|l|l|l|}
\hline No. & \multicolumn{1}{|c|}{ Faktor } & \multicolumn{1}{|c|}{ Tipe } & Yang Paling Dominan \\
\hline 1 & Keseluruhan Butir & Tipe Kepemimpinan & Setuju \\
\hline 2 & F1 & Tipe administrative/ eksekutif & Setuju \\
\hline 3 & F2 & Tipe demokratik & Setuju \\
\hline 4 & F3 & Tipe populistik/nasionalistik & Kurang Setuju \\
\hline 5 & F4 & Tipe karismatik & Setuju \\
\hline 6 & F5 & Otoriter/otokratis & Setuju \\
\hline
\end{tabular}

Tabel 6. Kecenderungan Tipe Kepala Sekolah

\begin{tabular}{|c|c|c|c|c|c|c|c|}
\hline No. & Sekolah & $\begin{array}{c}\text { F1 } \\
\text { Administrative/ } \\
\text { eksekutif }\end{array}$ & $\begin{array}{c}\text { F2 } \\
\text { Demokratik }\end{array}$ & $\begin{array}{c}\text { F3 } \\
\text { Populistik/ } \\
\text { nasionalistik }\end{array}$ & $\begin{array}{c}\text { F4 } \\
\text { Karismatik }\end{array}$ & $\begin{array}{c}\text { F5 } \\
\text { Otoriter/ } \\
\text { otokratis }\end{array}$ & $\begin{array}{c}\text { Jumlah } \\
(\%)\end{array}$ \\
\hline 1 & SD & 20 & 23 & 17 & 20 & 20 & 100 \\
\hline 2 & SMP & 21 & 23 & 19 & 18 & 19 & 100 \\
\hline 3 & SMA & 16 & 43 & 13 & 14 & 14 & 100 \\
\hline
\end{tabular}


tidak mutlak dan bersedia melimpahkan sebagian wewenang kepada bawahan; serta keputusan dan kebijakan dibuat bersama antara pimpinan dan bawahan; (b) komunikasi berlangsung secara timbal balik (antara pimpinan dan bawahan maupun sesama bawahan); (c) pengawasan terhadap sikap, tingkah laku, perbuatan atau kegiatan para bawahan dilakukan secara wajar; (d) prakarsa dapat datang dari pimpinan maupun bawahan dan banyak kesempatan bagi bawahan untuk menyampaikan saran, pertimbangan atau pendapat; dan (e) tugastugas kepada bawahan diberikan dengan lebih bersifat permintaan dari pada intruksi. Pimpinan memperhatikan dalam bersikap dan bertindak, adanya saling percaya, saling menghormati.

Gaya kepemimpinan delegatif menurut Lewin, Lippitt, \& White (1939) menyatakan ciri-ciri gaya ini adalah: (a) pemimpin memberikan kebebasan kepada bawahan, (b) pemimpin sangat paham dengan pekerjaan bawahan dan pemimpin jarang memberi arahan, (c) pemimpin dalam lingkaran politik, takut tidak dipilih kembali, (d) keputusan diserahkan kepada bawahan untuk menyelesaikan permasalahannya sendiri, dan (e) tidak ada komunikasi partisipatif dan keterlibatan pemimpin dalam workforce. Sedangkan Nawawi (2003) menyebutkan termasuk rendah dukungan dan rendah pengarahan G4 (Delegatif) dengan ciri-ciri: pemimpin mendelegasikan keputusan-keputusan dan tanggung jawab pelaksanaan tugas kepada bawahan, pimpinan mendiskusikan masalah bersama-sama dengan bawahan, dan proses pembuatan keputusan didelegsikan secara keseluruhan kepada bawahan. Menurut teori Contingency Theory Leadership dengan ciri-ciri pemimpin memberi perhatian pada tugas yang rendah dan perhatian hubungan manusia rendah.

Gaya militeristik/otokratis sesuai dengan gaya kepemimpinan menurut ahli Lewin, Lippitt, \& White (1939) yaitu Autocratic Leadership yang mempunyai ciri-ciri: (a) adanya kepatuhan penuh dari bawahan dan bawahan tidak membangkang, (b) keputusan, kebijakan, prosedur, peraturan, tujuan organisasi berdasarkan berdasar pemikiran sendiri, (c) jarang sekali menerima masukan orang lain, (d) keputusan yang diambil langsung dan final dan bersifat absolute, (e) pemimpin mengontrol bawahan dan menerapkan peraturan yang sangat ketat, (f) menganggap bawahan tidak mempunyai kemampuan dan keahlian serta bawahan tidak mengerti tugas-tugasnya, dan (g) bawahan tidak menghasil- kan inovasi, perubahan, perkembangan organisasi. Menurut Lewin, Lippitt, \& White (1939) dengan gaya otokratis yang mempunyai ciri-ciri: (a) wewenang mutlak, keputusan, dan kebijakan terpusat pada pemimpin; (b) komunikasi berlangsung satu arah dari pimpinan kepada bawahan; dan tidak ada kesempatan bagi bawahan untuk memberikan saran pertimbangan atau pendapat; (c) pengawasan terhadap sikap, tingkah laku, perbuatan atau kegiatan para bawahannya dilakukan secara ketat; (d) lebih banyak kritik dari pada pujian, dan (e) menuntut prestasi dan kesetiaan sempurna dari bawahan tanpa syarat, cenderung adanya paksaan, ancaman, dan hukuman.

Gaya eksploitatif sesuai dengan pendapat Rensis Likert (dalam Thoha, 2003) yaitu sistem 1 (pemimpin bergaya exploitive-authoritative) yang mempunyai ciri-ciri: sedikit memiliki kepercayaan pada bawahan dan bersikap paternalistik, suka mengeksploitasi bawahan, cara memotivasi bawahan dengan ketakutan dan hukuman, diselang seling memberikan penghargaan secara kebetulan, komunikasi ke bawah, dan pengambilan keputusan di tingkat atas saja.

Gaya konsultatif sesuai dengan pendapat ahli Rensis Likert (dalam Thoha, 2003) Sistem 3 (pemimpin bergaya konsultatif) yang mempunyai ciri-ciri sebagai berikut. (1) Pemimpin sedikit percaya kepada bawaha, melakukan pengendalian atas keputusan yang dibuat, melakukan partisipasi. (2) Pola hubungan ke atas dan ke bawah. Bawahan merasa sedikit bebas untuk membicarakan sesuatu yang bertalian dengan tugas pekerjaan dengan atasan. (3) Keputusan yang luas pada tingkat atas dan keputusan khusus pada tingkat bawah. Selain itu Nawawi (2003) menyebutkan bahwa tinggi pengarahan dan tinggi dukungan G2 (Konsultatif) yang mempunyai ciriciri (a) pemimpin banyak mengarahkan dan banyak dukungan, (b) pemimpin bersedia diberi masukan dari bawahan, dan (c) pemimpin tetap memberikan pengawasan dan pengarahan dalam penyelesaian tugas-tugas bawahan.

\section{Tipe Kepemimpinan Kepala Sekolah SD, SMP, dan SMA Negeri di Kota Malang}

Tipe kepemimpinan yang dimiliki Kepala Sekolah SD, SMP, dan SMA Negeri di Kota Malang dikelompokkan menjadi 5 macam yaitu: administratif/eksekutif, demokratis, populistik/nasionalistik, karismatik, dan otoriter/otokratis. Tipe yang per- 
tama adalah administrative/eksekutif sesuai dengan Muflihin (2008) yaitu administratif/eksekutif yang mempunyai ciri-ciri: (a) pemimpin yang mampu menyelenggarakan tugas-tugas administrasi secara efektif, (b) pemimpinnya biasanya terdiri dari teknokrat-teknokrat dan administratur-administratur yang mampu menggerakkan dinamika modernisasi dan pembangunan, (c) tercipta sistem administrasi dan birokrasi yang efisien dalam pemerintahan, dan (d) adanya perkembangan teknis yaitu teknologi.

Tipe demokratis sesuai dengan pendapat Rivai (2004:58) yaitu demokratis yang menyatakan bahwa kekuasaan pada bawahan. Sesuai pendapat Terry (1997) yaitu tipe kepemimpinan demokratis (democratic leadership) yang mempunyai ciri-ciri berusaha bertanggung jawab untuk mencapai tujuan bersama, semua anggota ikut dalam segala kegiatan: perencanaan, penyelenggaraan, pengawasan, penilaian. Semua anggota dianggap sebagai potensi yang berharga dalam usaha pencapaian tujuan. Menurut Muflihin (2008) yaitu tipe pemimpin demokratis dengan ciri-ciri: (a) pemimpin menggerakkan bawahan selalu bertitik tolak dari pendapat bahwa manusia itu adalah mahluk yang termulia di dunia, (b) selalu berusaha menselaraskan kepentingan dan tujuan pribadi dengan kepentingan organisasi, (c) senang menerima saran, pendapat dan bahkan dari kritik bawahannya, (d) mentolerir bawahan yang membuat kesalahan dan berikan pendidikan kepada bawahan agar jangan berbuat kesalahan dengan tidak mengurangi daya kreativitas, inisiatif dan prakarsa dari bawahan, (e) lebih menitikberatkan kerjasama dalam mencapai tujuan, (f) selalu berusaha untuk menjadikan bawahannya lebih sukses daripadanya, dan (g) berusaha mengembangkan kapasitas diri pribadinya sebagai pemimpin.

Tipe populistik/nasionalistik yang menyebutkan ciri-cirinya antara lain: (a) pemimpin berpegang teguh pada nilai-nilai masyarakat yg tradisional, (b) tidak mempercayai dukungan kekuatan serta bantuan hutang luar negeri, dan (c) kepemimpinan jenis ini mengutamakan penghidupan kembali sikap nasionalisme.

Tipe karismatik pemimpin menurut Muflihin (2008) yang mempunyai ciri-ciri diberkahi dengan kekuatan gaib (supernatural powers), perlu dikemukakan bahwa kekayaan, umur, kesehatan, profil pendidikan dan sebagainya. Selain itu memiliki daya tarik yang sangat memikat sehingga mampu memperoleh pengikut yang jumlahnya kadang-ka- dang sangat besar (Seseorang yang dikagumi oleh banyak pengikut meskipun para pengikut tersebut tidak selalu dapat menjelaskan secara konkret mengapa orang tersebut dikagumi).

Tipe otoriter menurut Terry (1997) yaitu tipe kepemimpinan otoriter (autoritotian leadership) yang mempunyai cirri-ciri bekerja keras, sungguhsungguh, teliti, dan tertib, serta bekerja menurut peraturan yang berlaku secara ketat dan instruksiinstruksi harus ditaati. Muflihin (2008) yaitu tipe pemimpin otokratis mempunyai ciri-ciri: (a) menganggap bahwa organisasi adalah milik pribadi. Mengidentikkan tujuan pribadi dengan tujuan organisasi. Menganggap bahwa bawahan adalah sebagai alat semata-mata; (b) tidak mau menerima kritik, saran dan pendapat dari orang lain karena dia menganggap, (c) selalu bergantung pada kekuasaan formal, dan (d) dalam menggerakkan bawahan sering mempergunakan pendekatan (approach) yang mengandung unsur paksaan dan ancaman.

Banyak diantara gaya dan tipe kepemiminan yang tidak terakomodasi dalam penelitian ini, diantaranya untuk gaya kepemimpinan yaitu: birokratik, Laissez Faire, gaya kepemimpinan efektif (eksekutif), gaya kepemimpinan efektif (developer), benevolent autocrat, compromiser, missionary, lari dari tugas/ deserter), partisipative group, Instruktif, dan lain sebagainya. Sedangkan untuk tipe kepemimpinan yang tidak terakomodasi dalam penelitian ini antara lain: kendali bebas, tipe kepemimpinan pribadi (personal leadership), non pribadi (non personal leadership, paternalistis leadership, tipe kepemimpinan menurut bakat (indogenious leadership), tipe pemimpin militeristik, dan tipe pemimpin paternalistis.

\section{Gaya Kepemimpinan Paling Dominan Kepala SD, SMP, dan SMA Negeri di Kota Malang}

Hasil penelitian menunjukkan faktor 1 gaya demokratik hasilnya setuju, faktor 2 gaya delegatif kebanyakan setuju, faktor 3 gaya militeristik banyak yang menyatakan kurang setuju, faktor 4 gaya eksploitatif kebanyakan kurang setuju, dan faktor 5 gaya konsultatif kebanyakan setuju. Bahwa di tingkat SD kepala sekolah cenderung mempunyai gaya exploitative, jika di tingkat SMP gaya kepala sekolah cenderung konsultatif, dan di tingkat SMA gaya kepala sekolah cenderung exploitative juga. Berdasarkan hasil penelitian ini, gaya demokratik adalah yang kebanyakan dilakukan oleh kepala se- 
kolah di Kota Malang, selanjutnya gaya delegatif dan gaya konsultatif. Gaya militeristik dan gaya eksploitatif merupakan gaya yang kurang disetujui oleh kepala sekolah baik di SD, SMP, maupun SMA Negeri. Walaupun kurang disetujui, tetapi dalam kenyataannya sehari-hari baik di tingkat SD dan SMA cenderung mempunyai gaya eksploitatif, sedangkan di SMP cenderung menggunakan gaya konsultatif.

Seharusnya kepala sekolah baik di SD, SMP, maupun SMA Negeri kepala sekolah sudah menyadari betapa pentingnya keterlibatan bawahan untuk menunjang pekerjaan sehari-hari dalam mencapai tujuan sekolah. Adanya kerjasama dengan tim untuk mendapatkan hasil yang maksimal, hal ini kepala sekolah masih menjunjung tinggi nilainilai luhur nenek moyang kita yaitu gotong royong, menghormati harkat dan martabat manusia dalam kehidupan di sekolah. Gaya militeristik dan gaya eksploitatif tidak cocok diterapkan dalam dunia pendidikan, karena terlalu kaku dengan sistem komando. Sedangkan di dunia pendidikan sekarang ini cenderung bersifat humanistik daripada behavioristik.

\section{Tipe Kepemimpinan yang Dominan Kepala Sekolah SD, SMP, dan SMA Negeri di Kota Malang}

Hasil analisis data penelitian menunjukkan faktor 1 tipe kepemimpinan administratif atau eksekutif kebanyakan kepala sekolah menyatakan setuju, faktor 2 tipe demokratik kebanyakan kepala sekolah menyatakan setuju, faktor 3 tipe populistik/ nasionalistik kebanyakan kepala sekolah menyatakan kurang setuju, faktor 4 tipe karismatik cenderung setuju, dan faktor 5 tipe otoriter/otokrasi cenderung setuju. Untuk tipe kepemimpinan pendidikan di tingkat SD hingga SMA cenderung demokratik.

Dari hasil ini kepala sekolah masih melaksanakan tugas-tugas administrasi sekolah terutama di Sekolah Dasar, jika di SMP dan SMA tugas administrasi sudah dipegang oleh tenaga administrasi sekolah (TAS). Di tingkat Sekolah Dasar tidak mempunyai tenaga administrasi. Kegiatan administrasi dibantu oleh guru-guru yang ada dan ada juga guru bantu/honorer. Bagi Sekolah Dasar yang bagus memang sudah ada tenaga administrasi sekolah, sehingga kepala sekolah berkurang dalam mengerjakan tugas-tugas administrasi.
Tipe populistik/nasionalistik kurang disetujui, dikarenakan kepala sekolah sekarang masih berpegang teguh pada nilai-nilai masyarakat yang tidak tradisional tetapi berpegang teguh pada nilainilai dan norma masyarakat yang baik dan sudah disesuaikan dengan keadaan zaman. Dengan adanya globalisasi sekarang ini seseorang/negara sudah tidak lagi bisa berdiri sendiri tetapi juga kerjasama dengan orang lain dan negara lain sangat diperlukan demi memajukan bangsa dan Negara. Begitu juga dengan kepala sekolah di Kota Malang saat ini perlu adanya kerjasama dengan guru/sekolah lain demi kemajuan sekolah yang mereka pimpin. Kepala sekolah mengutamakan sikap nasionalisme yang disesuaikan dengan keadaan zaman sekarang.

Jadi untuk tipe kepemimpinan baik di SD hingga SMA di Kota Malang sudah mempunyai kecenderungan memilih kepemimpinan secara demokratis, tetapi dalam kenyataan di lapangan sehari-hari yang muncul bahwa kepala sekolah di SD dan SMA malah kenderung exploitative, di tingkat SMP cenderung konsultatif. Seharusnya demi kemajuan pendidikan yang bersifat memanusiakan manusia, maka hendaknya baik apa yang ada di pemikiran kepala sekolah dengan apa yang dilakukan seharihari mempunyai kecenderungan yang sama yaitu memiliki gaya dan tipe demokratis. Hasil penelitian Burhanuddin dan Sunarni (2017) menyatakan tipe budaya organisasi mewarnai organisasi sekolah meliputi tipe birokratis, supportif, inovatif, market, adhokrasi, dan klan. Kesemua tipe memiliki pengaruh signifikan terhadap perilaku dan efektivitas kepemimpinan sekolah meliputi usaha-usaha kepala sekolah dalam (1) pengembangan visi, misi, dan tujuan organisasi, (2) pengelolaan sumber daya manusia, (3) pelaksanaan fungsi sebagai manajer, (4) pelaksanaan peranan sebagai leader, (5) peningkatan professional guru, dan (6) pengembangan iklim organisasi sekolah.

\section{SIMPULAN DAN SARAN}

\section{Simpulan}

Penelitian ini disimpulkan bahwa: (1) gaya Kepemimpinan yang dimiliki Kepala Sekolah SD, SMP, dan SMA Negeri di Kota Malang dikelompokkan menjadi 5 macam gaya yaitu demokratik, delegatif, militeristik/otokratis, eksploitatif, dan konsultatif. (2) Tipe kepemimpinan dikelompokkan menjadi 5 macam yaitu administratif/eksekutif, 
demokratis, populistik/ nasionalistik, karismatik, dan otoriter/otokratis. (3) Gaya kepemimpinan yang paling dominan yang dimiliki kepala sekolah SD, SMP, dan SMA Negeri di Kota Malang adalah: (a) secara keseluruhan jawaban yang paling banyak kepala sekolah baik SD, SMP, dan SMA Negeri menjawab setuju, b) untuk faktor 1 (F1=gaya demokratik) yang paling dominan kepala sekolah menjawab sangat setuju, (c) untuk faktor 2 (F2=gaya delegatif) yang paling dominan kepala sekolah menjawab setuju, (d) untuk faktor 3 ( $\mathrm{F} 3=$ gaya militeristik/otokratis) yang paling dominan kepala sekolah menjawab kurang setuju, (e) untuk faktor 4 (F4=gaya eksploitatif) yang paling dominan kepala sekolah menjawab kurang setuju, dan (f) untuk faktor 5 (F5=gaya konsultatif) yang paling dominan kepala sekolah menjawab setuju. Dan (4) tipe kepemimpinan yang dimiliki Kepala Sekolah SD, SMP, dan SMA di Kota Malang yang paling dominan adalah: (a) secara keseluruhan yang paling dominan kepala sekolah baik SD, SMP, dan SMA Negeri menjawab setuju, (b) untuk faktor 1 (F1=tipe administrative/eksekutif) yang paling dominan kepala sekolah menjawab setuju, untuk faktor 2 (F2=tipe demokratik) yang paling dominan kepala sekolah menjawab setuju, (c) untuk faktor 3 (F3=tipe populistik/nasionalistik) yang paling dominan kepala sekolah menjawab kurag setuju, (d) untuk faktor 4 (F4=tipe karismatik) yang paling dominan kepala sekolah menjawab setuju, dan e) untuk faktor 5 ( $F 2=$ otoriter/otokratis) yang paling dominan kepala sekolah menjawab setuju.

\section{Saran}

Berdasarkan hasil penelitian ini diharapkan calon kepala sekolah, hendaknya memahami betul tentang gaya dan tipe kepemimpinan dan memahami orang lain, sehingga kelak dapat menerapkan gaya dan tipe apa yang dapat digunakan untuk memimpin bawahan. Hendaknya kepala sekolah di Kota Malang baik SD, SMP, dan SMA Negeri memilih gaya dan tipe yang disesuaikan dengan kondisi yang ada di sekolah masing-masing. Perlu adanya pembahasan gaya dan tipe kepemimpinan yang sesuai dengan bangsa Indonesia bagi peneliti khususnya di bidang administrasi pendidikan. Dan untuk mendukung hasil penelitian ini dengan maksimal, perlu adanya penelitian kembali tentang gaya dan tipe sesuai grand theory. Teori-teori yang lain hendaknya dimasukkan sesuai dengan bidang masing-masing untuk memperkaya grand theorynya.

\section{DAFTAR RUJUKAN}

Burhanuddin dan Sunarni. 2017. Pengukuran Budaya Organisasi dan Pengaruhnya Terhadap Efektivitas Kepemimpinan di Sekolah Dasar. Jurnal Sekolah Dasar, 26 (1), hlm 1-13.

Gandz, J., \& Murray, V. V. 1980. The Experience of Workplace Politics. Academy of Management Journal, 23(2), 237-251.

Lewin, K., Lippitt, R., \& White, R. K. 1939. Patterns of Aggressive Behavior in Experimentally Created "Social Climates". The Journal of Social Psychology, 10(2), 269-299.

Mondiani, T. 2012. Pengaruh Kepemimpinan Transformasional dan Kompensasi Terhadap Kinerja Karyawan PT. PLN (PERSERO) UPJ Semarang. Jurnal Administrasi Bisnis, 1(1). (Online). https://ejournal.undip.ac.id/index. php/janis/article/view/4317

Mufidah, I. 2009. Hubungan Gaya Kepemimpinan Kepala Sekolah dan Iklim Sekolah dengan Kinerja Tenaga Administrasi Sekolah (TAS) di SMPN Kota Malang. Skripsi Tidak Diterbitkan. Malang: UM.

Muflihin, M. H. 2008. Kepemimpinan Pendidikan: Tinjauan terhadap Teori Sifat dan Tingkahlaku. Insania, 13(1), 67-86.

Nawawi, Hadari. 2003. Kepemimpinan Mengefektifkan Organisasi. Yogyakarta: Gajah Mada University Press.

Peraturan Menteri Pendidikan Nasional Republik Indonesia No. 13 tahun 2007 tentang Standart Kepala Sekolah. (Online). http://www. wordpress.com. Diakses 25 Pebruari 2013.

Pratiguna, A.A., Marchaban, dan Nugroho, E.P. 2013. Pengaruh Gaya Kepemimpinan terhadap Produktivitas Kerja dengan Faktor Pemediasi Motivasi dan Kemampuan Kerja Karyawan di Dinas Kesehatan Kabupaten Klaten. Disertasi Tidak Diterbitkan. Malang: UGM.

Pujianto, P. 2015. Fungsi Kepala Sekolah dalam Membina Kompetensi Pedagogik Guru. Manajer Pendidikan, 9(6), 760-768.

Reza, R.A. 2010. Pengaruh Gaya Kepemimpinan, Motivasi dan Disiplin Kerja terhadap Kinerja Karyawan PT Sinar Santoso Banjarnegara. Skripsi Tidak Diterbitkan. Semarang: Universitas Diponegoro. 
Rivai, V. 2004. Kepemimpinan dan Perilaku Organisasi. Jakarta: PT Raja Grafindo Persada.

Soetopo, H. 2010. Kepemimpinan Pendidikan. Malang: FIP UM.

Tangkilisan, H. N. S. 2005. Manajemen Publik. Jakarta: Grasindo.

Terry, G.R. 1997. Prinsip-Prinsip Manajemen. Jakarta: Bumi Aksara.
Thoha, M. 2003. Kepemimpinan dalam Manajemen, Suatu Pendekatan Perilaku. Jakarta: PT Raja Grafindo Persada.

Undang-Undang Nomor 32 Tahun 2004 tentang Pemerintah Daerah. (Online). http://www.kpu. go.id. Diakses 25 Pebruari 2013. 